ISSN 2078-6441. Вісник Львівського університету. Серія географічна. 2018. Випуск 52. С. 89-99.

Visnyk of the Lviv University. Series Geography. 2018. Issue 52. P. 89-99.

http://dx.doi.org/10.30970/vgg.2018.52.10172

911.37

\author{
иросл в ністрянський ${ }^{1}, \quad$ т лія ністрянськ ${ }^{2}$ \\ 1 ввівський н ціон льний університет імені в н \\ вул. . орошенк , 41, 79007, м. ввів, кр їн, \\ e-mail:m_dnister@ukr.net \\ 2 ціон льний університет “ ввівськ політехнік ”, \\ вул. енер л упринки, 130, 79057, м. ьвів, кр їн
}

дослідженні проблем з селення кр їнських рп т н йбільш дискусійними є пит ння ч су з селення, ролі різних мігр ційних рухів т етнічного скл ду переселенців. сторичні джерел з свідчують, що до ст. суцільної мережі поселень у гірських р йон х кр їнських рп т не було, одн к н передодні того ч су д вньоукр їнське н селення доволі інтенсивно освоюв ло безпосередньо передгірські р йони, тр нск рп тські шляхи, створюв ло в гірській місцевості оборонні пункти т пров дило різне вибіркове природокористув ння. огляду н соці льноекономічні й безпекові потреби д вньоукр їнського н селення передгірських територій основний мігр ційний рух відбув вся з рівнинних місцевостей по течії гірських рік до їхніх витоків, зокрем , з території рик рп ття і ідк рп ття, т кож олині й оділля. одібність ойконімів по обидв боки кр їнських рп т підтверджують впливовість тр нс к рп тських колоніз ційних рухів, які 3 лишили сліди в гірській місцевості. ізні історичні й етногр фічні ртеф кти свідч ть про в жливу роль у процес х з селення к рп тської гірської місцевості південної колоніз ції, тобто переселення в цей регіон н селення з території н межі середнього і нижнього ун ю, історичних р нсільв нії т олдови впродовж - VI ст., яких у ечі осполитій т в деяких інших держ в х політично ідентифікув ли як “волоські землі”. сновним етносоці льним компонентом південної колоніз ції бул людність слов'яно-руського походження. селення гірських р йонів кр їнських рп т вплинуло і н формув ння соці льної структури укр їнського суспільств , зокрем , н поширення укр їнської дрібної шляхти, яку первинно сформув ли ос дники сіл т їхні родини. піввідношення різних груп переселенців з півдня, півночі, з ходу і сходу, т кож уст лення х р ктерних рис тр диційного господ рств й тр диційної культури під впливом різних природних умов зумовило формув ння укр їнських к рп тських етногр фічних груп (бойків, лемків, гуцулів).

лючові слов : з селення кр їнських рп т, південн колоніз ція, укр їнські етногр фічні групи, топонімія кр їнських рп т, тр нск рп тські переселення.

селення, соці льно-економічне освоєння і культурний розвиток гірських р йонів т к чи ін кше були пов'яз ні з прилеглими рівнинними територіями, одн к через скл дніші природні умови з вжди м ли свою специфіку. е стосується і гірських р йонів

рп т, які з огляду н їхню протяжність і конфігур цію, природну 6 р'єрність, виділялися межовим положенням шодо різних політичних і етнокультурних одиниць, що й

(C) ністрянський ., ністрянськ ., 2018 
зумовило скомпліков ність процесів з селення. роте хідні ( кр їнські) рп ти ${ }^{1}$ в цьому контексті м ють свої особливості, дже в етнокультурному спекті безпосередньо прилеглі з з ходу т сходу до гірських р йонів суч сної укр їнської ч стини рп т рівнинні території не були різнорідними: т м перев ж ло споріднене д вньоукр їнське н селення. ериторі льно-політичні впливи суттєво ускл днюв ли процеси з селення, оскільки внутрішні хребти кр їнських рп т н ч с формув ння суцільної мережі поселень ( - V ст.) були кордоном між лицько- олинською держ вою, пізніше ольським оролівством, т горським королівством, південн ч стин 3 V ст. перебув л під впливом олд вського князівств . жливими були й т кі геополітичні чинники, які вплив ли н м сові тогоч сні мігр ції в івденно- хідній вропі, як етнополітичні процеси в івнічному ричорномор'ї т н івночі лк н і територі льн експ нсія см нської імперії. тже, усі обст вини геополітичного положення свідч ть про те, що освоєння гірських р йонів кр їнських рп т відбув лося в умов х вз ємодії скл дних тогоч сних міжн родно-політичних чинників.

сі спекти з селення кр їнських рп т виклик ли і виклик ють гострі дискусії серед вторів різних кр їн, тому широкою й різнобічною $є$ н уков й н уковопопулярн літер тур, присвячен цій проблем тиці. йбільш дискусійними $є$ т кі пит ння: 1) ч су з селення; 2) ролі різних мігр ційних рухів; тр ктув ння чинників т мех нізмів колоніз цій; 3) етнічного скл ду переселенців т впливу різноспрямов них переселень н диференці цію етногр фічних особливостей кр їнських рп т. методологічних підход х до цих пит нь виник є низк проблем нижчого рівня. окрем , щодо причин з кл д ння сіл н т к зв ному волоському пр ві, впливу південної колоні3 ції н формув ння соці льного скл ду н селення регіону т ін.

узлове зн чення етнокультурної проблем тики з селення кр їнських рп т зумовило в жливу особливість н лізу проблеми - етнополітичну 3 нг жов ність н ціон льних історіогр фій, що пов'яз но з певною тенденційністю в обгрунтув ннях історичних етнічних територій і меж, політичних пр в н територію і н віть 3 творенням н ціон льних геополітичних доктрин. омітн упередженість уже виявляється у вихідному пункті проблеми - визн ченні ч су м сового з селення, тобто формув ння цілісної мережі поселень. еред укр їнських істориків й кр єзн вців ще поширені уявлення про глибоку д вність існув ння широкої мережі поселень у рп т х, як сяг є доісторичних ч сів. цьому р зі простежується екстр поляція ситу ції з передгірської місцевості н гірські р йони, обгрунтув ння д вності з селення розгляд ють як спосіб доведення втохтонності укр їнців у хідних рп т х. оч відомий укр їнський дослідник проблем з селення рп т . ошко ще 1976 р. з зн чив, що до IV ст. кр їнські рп ти не були “пусткою”, одн к “з н явності родючих угідь н рик рп тті (...) т при зн чно меншій кількості н селення не було ніякої економічної необхідності йти в гори т освоюв ти землі, менш прид тні для обробітку” [3, с. 27]. одноч с в польській історіогр фії поч ткиз селення перев жно пов'язують з переходом історичної личини до скл ду ольського оролівств , недооцінюючи розселенські тенденції попередніх періодів, зокрем , у лицько- олинській держ ві другої половини -першої половини IV ст., зумовлені н с мперед виклик ми безпеки, тобто потребою зміцненням кордонів держ ви, з хистом шляхів сполучення, т кож економічними потреб ми. е

1 ід кр їнськими рп т ми тут розуміємо: ) у вужчому зн ченні - ч стину рп тської дуги в меж х суч сної кр їни; б) у ширшому зн ченні - ту ч стину хідних і хідних рп т, де в першій половині ст. етнічні укр їнці ст новили більшість. 
одн х р ктерн рис польської історіогр фії в підход х до з селення кр їнських рп т - перебільшення впливу неукр їнського етнічного компонент . одібні погляди н цю проблему вл стиві й іншим н ціон льним школ м, н с мперед румунській, чеській. оряд з етнополітичною упередженістю тут простежується неготовність сприйняти руське н селення -XIV ст. як д вньоукр їнське. крім того, не можн не бр ти до ув ги, що пріоритетність в освоєнні території - це пит ння н ціон льно-політичної престижності, як є скл довою історично-культурних тр дицій. тому визн в ти с ме 3 укр їнцями, які трив лий ч с були бездерж вним н родом, пріоритетність 3 селення хідних рп т ідеологічно 3 нг жов ним (тією чи іншою мірою) втор м було непросто.

жливим ргументом у визн ченні витоків м сового освоєння гірських м сивів кр їнських рп тє творення ще в попередні історичні періоди низки поселень безпосередньо н межі рп т т ередк рп ття, н с мперед у місцях виходу н рівнину гірських рік ( пору, ністр, трию, ж), які існув ли вже в ч си племінних слов'янських держ в т иївської усі [3, с. 17]. порними центр ми їхнього розселення тут були передгірські т окремі гірські оборонні пункти, зокрем , розміщені біля суч сних сіл ульчиці, чин , ородище, розьово, опуш нк - омин , п с, ілець, урочки, ур'є, опільниця [7], т кож, імовірно, й біля с. ерезів. еякі історичні м тері ли з свідчують існув ння мережі оборонних пунктів н тодішніх тр нск рп тських шлях х [10]. думку . ящук, сліди т ких оборонних пунктів є і в топоніміці сіл, зокрем , урківського т т рос мбірського р йонів ьвівської обл. [9, с. 25]. крім оборонних і тр нспортних потреб, виникнення цих поселень було пов'яз не, зокрем , 3 соляними промисл ми [13]. тже, з ур хув нням усіх історичних ре лій можн зробити н укове припущення, що хоч до ст. суцільної мережі поселень у рп т х не могло бути, т н передодні того ч су д вньоукр їнське н селення доволі інтенсивно освоюв ло безпосередньо передгірські р йони, тр нск рп тські шляхи, створюв ло оборонні пункти т пров дило різне вибіркове природокористув ння вже в гірській місцевості.

йскл дніше методологічно визн читись щодо ролі різних мігр ційних рухів у з селенні кр їнських рп т. ин мічний х р ктер історико-геогр фічних процесів упродовж - V ст., т кож геогр фічне положення кр їнських рп т н межі різних політичних впливів з свідчують, що їхнє 3 селення не могло м ти однолінійного х p ктеру, було результ том різноспрямов них колоніз ційних рухів. дн к дискусійними є пит ння: які с ме мігр ції відігр ли провідну роль у з селенні кр їнських рп т? чи одн ковою мірою це стосується всіх ч стин регіону? скільки відповіді н ці пит ння т кож охоплюють етнокультурні спекти, то в підход х до цієї проблеми теж помітною є політичн упередженість.

огляду н соці льно-економічні й безпекові потреби д вньоукр їнського н селення передгірських територій основний мігр ційний рух відбув вся з рівнинних місцевостей по течії гірських рік до їхніх витоків, зокрем , з території рик рп ття і ідк рп ття, т кож олині і оділля. ро це свідчить поширення в гірській місцевості ойконімів, які дублюють н зви передк рп тських і 3 к рп тських поселень, розкрив ючи т кож основний мех нізм переселення, коли споч тку з кл д ли н селений пункт у передгірській місцевості (н с мперед з огляду н потреби оборони, охорони шляхів сполучення т місць видобув ння солі), пізніше вихідці з цього поселення з сновув ли вже нові н селені пункти в гор х 3 т кою ж н звою. кі розселенські тенденції, н які вперше звернув ув гу ом рницький[8], можн простежитин прикл ді однойменних 
поселень: $\quad$ бовець (з т кою н звою є сел в теперішньому трийському, огородч нському i колівському р йон х), ропивник (у луському, олинському i рогобицькому р йон х), імн (тепер колишнє село в гміні ірч еремишльського повіту, еспублік ольщ, і в урківському р йоні), йд $н$ (у исменицькому, іжгірському $\mathrm{i}$ рогобицькому $\mathrm{p}$ йон х), укотин ( оломийський $\mathrm{i}$ урківський $\mathrm{p}$ йони) т ін. . ом рницький розкрив цей мех нізм з селення г лицької ч стини хідних рп т і н прикл д х т ких н селених пунктів, як урк, еньов , исоцьке, звиняче, в дівк, ом рники, ривк, п с, урочки, блуньк, вор т ін. [8]. 30 з ос дник ми сіл і їніми родич ми в рп ти рух л сь і деяк ч стин н селення 3 ередк рп ття, оділля т олині, тобто укр їнськ людність різних регіонів.

підст ви говорити і про н явність різної інтенсивності інших колоніз ційних рухів, зокрем, тр нск рп тських: 3 усі, пізніше ольщі й ечі осполитої, в горське королівство ін вп ки, які з лишили сліди в гірській місцевості. ро це т кож свідчить подібність ойконімів по обидв боки хідних рп т, н прикл д усний теперішнього еликоберезнянського р-ну к рп тської обл. і $y c н е$ урківського р-ну ьвівської обл., льниия рш вського р-ну к рп тської обл. й льник урківського р-ну ьвівської обл. ороткотрив ле перебув ння личини в скл ді горського королівств (1370-1387) т кож могло д ти певний поштовх тр нск рп тським переселенням.

ізні історичні й етногр фічні ртеф кти з свідчують в жливу роль південної колоніз ції в процес х з селення к рп тської гірської місцевості, тобто переселення в цей регіон н селення з території н межі середнього і нижнього ун ю, історичних р нсільв нії т олдови впродовж - VI ст., які в ечі осполитій т в деяких інших держ в х політично ідентифікув ли як “волоські землі” (звідси і поширен н зв південного колоніз ційного руху - “волоськ колоніз ція”). ме роль цього колоніз ційного руху досі сьогодні є н йбільш спірною. ермін “волоськ колоніз ція” з пропонув в польський історик . т дницький (1806-1866), тр ктуючи цей мігр ційний рух як переселення в хідні i івнічні рп ти здебільшого етнічно румунського н селення [19]. скільки ф кти переселення людей з р нсільв нії т олдови підтверджув л низк документів, зокрем, щодо н д ння пр в н $з$ селення сіл, поширення в рп т х і рик рп тті т кзв ного волоського пр в, відповідних топонімів ( олосянк (дВ поселення), елик олосянк, $\lambda$ олосянк, олошиново, олехів олоський т ін.), прізвищ ( олох, $\lambda x$, олошин, олощук т ін.) тощо, то своє б чення цієї проблеми н м г лося з свідчити широке коло укр їнських, польських, румунських, угорських, чеських і слов цьких істориків, т кож етнологи т соціологи різних кр їн, м ючи з цього приводу ч сто ді метр льно протилежні погляди.

еякі нові підходи, т водноч с і дод ткові “збурення” в н укове середовище $з$ приводу “волоської” колоніз ції, привнесли публік ції польського етнолог . обровольського (1894-1987). ме під його впливом поширеними, особливо серед польських істориків і етнологів, є низк грунтов них н геогр фічному детермінізмі стереотипів, які не сприяють об'єктивному розумінню проблеми. с ме: 1) з селення рп т, н його думку, - це н слідок стихійного й м сового переселення ж 3 лк нського півостров кочового п стушого н селення, зумовлене потреб мином дного скот рств , н с мперед у нових п совищ $\mathrm{x} ; 2$ ) основ переселенців - ром номовне н селення з домішк ми груп тюркського т лб нського походження і незн чним вкр пленням слов'янського н селення [18]. одібні погляди щодо етнічного х р ктеру переселенців у різний ч с висловлюв ли й інші польські н уковці ( . ерсовський, лугопольський), т кож 
деякі румунські ( . істор), чеські ( . длец) т ін. оширеною серед них методологічною хибою було й ототожнення усіх мешк нців, що прожив ли в сел х т к зв ного волоського пр в , з ром номовним н селенням. кі підходи не підтрим л інші з рубіжні вчені ( . p ндж лов, . лоупецький т ін.). ж ніяк не могли їх сприйняти й укр їнські н уковці, оскільки вони однозн чно суперечили етногеогр фічним ре ліям, поз як відр зу пост в ло пит ння: 1) як могло т к тр питись, що 3 результ т ми 3 селення хідних рп т і ч стково хідних рп т нібито ром номовним н селенням утворився клин укр їнської етнічної території, який, як уже з зн чено, простягнувся від

рм рощини ж до трів? 2) як могло н півкочове п стуше н селення 3 кл сти мережу постійних н селених пунктів, зн чн ч стин н селення яких тр диційно з йм л ся землеробством? ому у відповідь н очевидні недоречності, висунуті прихильник ми визн ч льної колоніз ції рп т п стушим ром номовним н селенням, деякі укр їнські історики хибно н м г лися зовсім мінімізув ти зн чення переселень 3 олдови i $\mathrm{p} \mathrm{H-}$ сільв нії в процесі освоєння хідних і хідних рп т. лише в суч сних умов х щор 3 ктивніше висловлюють думки [11] про те, що колоніз ція рп т 3 івдня, тобто 3 північних лк н, р нсільв нії, олдови, бул суттєвою, ле соці льно різнобічною, включ ючи переселення різних груп і осілого, і п стушого н селення, 3 етнічного погляду основу переселенців ж ніяк не ст новило ром номовне н селення.

одо етнічної ідентичності п стушого н селення, яке в кр їн х ентр льної і ентр льно- хідної вропи н зив ли волох ми, однозн чну відповідь д ти скл дно. історично-етногеогр фічного погляду очевидно, що ототожнюв ти ці групи п стухів 3 румунським етносом, як це ч сто робили окремі з рубіжні н уковці, не можн хоч б тому, що румунський етнос н той ч с ще ост точно не сформув вся. ожн ст вити пит ння лише про протором нські компоненти в “волоському середовищі”. скільки це н селення м ло низький рівень етнічної с мосвідомості, будучи лише субстр том формув ння модерних етнічних спільнот, то й з г лом про його окремі етнічні риси можн говорити лише 3 деякими мовними озн к ми. огляду н це у світовій т укр їнській н уковій літер турі й досі є т к різном нітність поглядів н цю проблему. К, історик і філолог . римич, посил ючись н підходи деяких європейських н уковців, ув ж є, що ті “волохи”, які прибули в рп ти, були “слов' янізов ним ром но-фр кійським елементом" [4, с. 111]. ожн погодитись з її висновком про те, що більшість п стухівволохів, які прийшли вже в хідні рп ти, були слов'яномовними, водноч с дискусійним є її твердження, що слов'яномовний х р ктер того н селення - це перев жно н слідок симіляційних процесів. пр вді, деякі групи ром номовного н селення під впливом слов'янських політичних утворень, н с мперед болг рських, т кож церковнослов'янського обряду, могли інтегрув тися у слов'янське середовище, проте їхня демогр фічн в г н вряд чи бул зн чною, дже досвід н ступних історичних періодів свідчить, що ром номовне н селення дуже повільно симілюв лося в слов'яномовні середовищ . ому, як з свідчують імен переселенців у 6 г тьох історичних документ х, середовище п стухів-волохів н ередньому ун ї і лк н х усе ж було неоднорідним, охоплюючи різні компоненти (південно-слов'янські, протором нські, руські т тюркські). думку . ивод p, “уже в кедонії “волохи” були етнічно зміш ними, ч сто дво-тримовними" [16].

ерез перев жне 3 няття п совищним тв ринництвом волох ми у - ст. могли н зив ти й етнічно неоднорідне п стуше н селення з хідної ч стини івнічного ричорномор'я, ч стин якого т кож згодом мігрув л н північ. я людність, як й історичні 
болохівці ${ }^{2}$ м л суспільну втономію, ле бул під великим політичним і культурним впливом усі як н йбільш розвинутої держ ви регіону, н слідуючи руські політичнопр вові, мовно-культурні й релігійні тр диції, зокрем інститут князів, воєвод, бояр, пр вові норми “ уської пр вди”, віз нтійський релігійний обряд т ін. обто через мех нізми дифузії нововведень, т кож безпосередні впливи руського етнічного компонент (це були т к зв ні вигн нці з руських земель, бродники т ін.) ідеї т досягнення усі своєрідно н кл д лися н тр диції п стушого етнічно неоднорідного н селення івнічного ричорномор'я і ереднього одун в'я, визн ч ючи його суспільно-політичну орг ніз цію і культурне обличчя. тже, з огляду н зн чне перев ж ння в той ч с н івнічних лк н х південнослов'янського н селення, його великий колоніз ційний потенці л, т кож в жливу роль руської скл дової в середовищі п стухів-волохів з хідної ч стини івнічного ричорномор'я, є підст ви вв ж ти, що вже в меж $x$ p нсільв нії с ме слов'янський компонент серед $m \kappa$ зв них волохів, які перейшли н осілий спосіб життя, кількісно $і$ культурно перев ж в. кі висновки підтверджують і лінгвістичні м тері ли (домінув ння південнослов'янських імен у відповідних історичних документ х), і різном нітні етногр фічні джерел (фольклорні, лінгвістичні), і поширеність т ких топонімів, як ня, рез, р гово, сій, ймовірно уп ни, осів, гор p гобр т т ін. ому, очевидно, з етнічного погляду основним етносоці льним компонентом південної колоніз ції були не ром номовні кочівники, перев жкно осіл людність слов'яно-руського походження. зн чення цих людей як “волохи” свідчило н с мперед про місце їхнього попереднього розселення, т кож прожив ння в сел х т к зв ного волоського пр в , у деяких вип дк х - н перев жне з няття тв ринництвом.

ізні методологічні підходи пов'яз ні і з тр ктув нням присутності руської людності в горському королівстві й, зокрем, р нсільв нії ( емигороді) впродовж - ст., як , імовірно, в н ступний період т кож бул втягнут в процес переселення в хідні рп ти. ро поширення руської людності в горському королівстві і р нсільв нії свідчить як низк топонімів, т к і зг дк в д вніх документ х - ст. про особливе політико- дміністр тивне утворення - уську м рку, щодо розміщення т походження якої серед істориків нем є одност йності. огляду н те, що утворення т ких політикодміністр тивних одиниць, як “м рки” т к чи ін кше було пов'яз не $з$ оборонними потреб ми ( в горському королівстві проблемними в цьому спекті були н с мперед південні і південно-східні території), т кож з ур хув нням поширення руської людності с ме р нсільв нія могл бути місцем лок ліз ції уської м рки.

ро присутність д вньоукр їнської людності в р нсільв нії з зн чило б г то відомих істориків, зокрем, i • рушевський, який н поч тку ст. конст тув в: “ емигороді вже нем русинів, вони “згинули”, можн ск з ти, н н шій п м'яті... лід русинів зост вся тут тільки в численних хоро- т топогр фічних н зв х..., м дяризов них, румунізов них, герм нізов них... Oroszi, Oroszfalva, Oroslugy, Rusesti, Russielu, Russdorf, Rusz і т.п.”. к с мо, н думку укр їнського історик, “експлу т ція соляних і рудних б г тств емигородських гір іде від слов'янських ос дників: окно, б ня, сольник - слов'янські н зви...”. жливо, що . рушевський однозн чно н голошув в, що “той слов'янський елемент був укр їнським” [5, с. 197]. ільшість укр їнських істориків ув ж є руське н селення підк рп тської ч стини горщини - ст. втохтонним.

2 еякі історики, зокрем, . етрушевич, . ом шівський, походження історичних болохівців пов'язують с ме з волох ми. 
дн к є й інші погляди. окрем , . олощук н підст ві н лізу великого м сиву історичних документів щодо переселень нобілітету (бояр, князів) т його оточення 3 території руських князівств, н с мперед лицько- олинського, до горщини впродовж -другої половини V ст. обгрунтув в і демогр фічне зн чення т ких переселень, у тому числі щодо створення мережі поселень з коренем “руський” [1]. ожн погодитись 3 втором, що деякі переселення г лицько-руської зн ті і могли м ти лок льне поселенське зн чення в тодішньому горському королівстві, проте сформув ти т ку широку мережу поселень (кільк десятків н селених пунктів лише з коренем “рус", очевидно, що було ще більше руських поселень з іншою н звою) ж ніяк не могли. е свідчить про деяку бсолютиз цію цього н пряму мігр цій (з усі до горщини) т його поселенського зн чення, у тому числі певну недооцінку зн чення мігр ційних рухів у зворотному н прямі ( 3 горщини до усі). ому більш вив женим є висновок про те, що руськ присутність в горському королівстві формув л ся як втохтонним н селенням, т к і мігр ціями 3 усі. зн чний вплив н ідентифік цію слов'янського н селення горського королівств, зокрем, p нсільв нії, 3 руською етнічністю поряд 3 с моусвідомленням могло м ти тр ктув ння його етнічної н лежності угорцями т предст вник ми інших н родів. н т ку зовнішню ідентифік цію цього н селення як русинів могли вплив ти не лише мовно-культурні особливості, й безпосереднє сусідство з уссю як впливовою розвинутою держ вою того ч су, т кож віз нтійський обряд т церковно-слов'янськ мов .

руською людністю т її політичною орг ніз цією пов'яз ні й поч тки держ вності олдови, яку згодом т кож у широкому розумінні поч ли в ольському королівстві т ечі осполитій ідентифікув ти як “волоську” землю, оскільки туди р зом зі слов'янським н селенням 3 р нсільв нії т л хії впродовж $\mathrm{V}$ ст. перейшл зн чн ч стин ром нського н селення, яке згодом, уже в н ступному столітті, у цій кр їні ст новило більшість. од льше формув ння політичної структури цієї держ ви визн ч лося н с мперед тр диціями лицько- олинської усі. е стосується ін зви пр вителя (господ р) т низки упр влінських пос д і соці льних ст нів (бояри), поширення руської (д вньоукр їнської) мови як споч тку єдинодерж вної, потім - другої держ вної (поряд $з$ молд вською). півночі олдови трив лий ч с, ж до середини XV ст., зберіг л сь T К руськ с моврядн територі льн одиниця, як ипинськ земля, н півдні були розселені бродники і берл дники. ошко припуск в, що після інкорпор ції личини ольським королівством в олдову могл переселятися й деяк ч стин г лицьких провідних верств [2, с. 33]. д ними суч сних молдовських істориків, русинське (д вньоукр їнське) н селення ще н поч тку V ст. ст новило близько $40 \%$ від усієї людності

олдови, у її північній ч стині - велику більшість [14, с. 15]. огляду н етнічний скл д н селення т особливе культурне середовище, олдову в тодішній вропі тр ктув ли як усо- л хію [12]. иділяючись н явністю зн чної кількості слов'яно-руської (д вньоукр їнської) людності, i р нсільв нія, і олдов , з оглядун н низку об'єктивних і суб'єктивних суспільно-політичних передумов, ст ли, почин ючи з ст., осередк ми іï емігр ції в північному н прямі, як і вплинул суттєво н з селення гірських к рп тських м сивів, т водноч с призвел до поступової ром ніз ції цих історичних обл стей. ідтвердженням м сової мігр ції руського н селення $р$ нсільв нії н північ $\epsilon$ і той фкт, що уже в ст., з слов ми . рушевського, н цій території руського н селення м йже не з лишилось [5, с. 198]. роте в жко погодитись з висновком вид т- 
ного історик, що воно симілюв ло. огічно припустити, що русинське (д вньоукр їнське) н селення р нсільв нії і олдови не симілюв лось, якр з переселилося в гірські р йони хідних і хідних рп т.

с дним пр вом в процесі з кл д ння сіл у більшості вип дків, н с мперед в т к зв них королівщин х, було т к зв не волоське пр во, яке відповід ло тр диціям т соці льно-економічним умов м прожив ння руського й південнослов'янського н селення в р нсільв нії т олдові й було декв тне умов м укр їнської гірської місцевості. одноч с н зв цього ос дного пр в і ст л, головно, чинником дезорієнт ції щодо етнічного скл ду поселенців. ме н цьому й відбулося н йбільше ф льсифік цій щодо неукр їнського х р ктеру цих н селених пунктів. евідповідність н зви етнічному х р ктеру поселення відр зу з ув жив . рушевський, з слов ми якого “імен цих волохів чисто руські” [6, с. 17]. підст ві іншого історичного документ він з зн ч є, що “волоські сел упр влялися руським пр вом” [6]. е свідчить про те, що переселенці $з$ р нсільв нії, пізніше і з олдови, ф ктично переносили н новоосвоєні землі тр диційні для своєї місцевості пр вовідносини, споріднені з д вньоруським пр вом, що відобр зилось і в слов'янських н зв х основних вл дних пос довців т територі льних підрозділів (князь, кр йник, кр їн ). ро це свідчить і тотожність звич євого пр в укр їнських поселень у гірській місцевості т в суміжних рівнинних $\mathrm{p}$ йон х. думку ндри, “під н звою “волоське пр во" діяв різновид укр їнського звич євого пр в " [17].

селення гірських р йонів кр їнських рп т з безпечило формув ння тут і деяких соці льно зн чущих явищ, зокрем, поширення укр їнської дрібної шляхти, яку первинно ст новили ос дники сіл т їхні родини, отрим вши відповідні відсільні прізвищ (від сіл вор - ворські, ом рники - ом рницькі, рушельниця - рушельницькі, тків - тківські тощо). умов, коли зн чн ч стин д внього руського боярств 3 різних причин з зн л полоніз ції, дрібн к рп тськ й передк рп тськ шляхт попри скл дні економічні умови, симіляційний тиск усе ж перев жно зберіг л руську (укр їнську) ідентичність т вірність пр восл вній і греко-к толицькій конфесійним тр диціям. скільки ос дники сіл, велику ч стку яких ст новили вихідці з “волоських" земель, усп дковув ли й інститут місцевого священик (споч тку це були пр восл вні священики, пізніше - греко-к толицькі), то їхні н щ дки, зокрем , родини чинських, ординських, p бовецьких, льницьких, убрицьких, іхновських, мінських, обилянських, ом рницьких, орчинських, р сівських, ропивницьких, рушельницьких, ульчицьких, дрехівських, ілецьких, рн вських, ерлецьких, йковських, ворських т б г то інших [15], утворили зн чний прош рок споч тку церковної інтелігенції, вже з ст. - й світської, ст вши з чин телями в розвитку укр їнської літер тури, те тру, живопису, особливо н терен х хідної кр їни, т кож відомими гром дсько-політичними діяч ми й н уковцями з г льноукр їнського зн чення.

собливості з селення кр їнських рп т упродовж - V ст. пояснюють і деякі особливості етногр фічної диференці ції цього регіону, спростовуючи, зокрем , різні ілюзорні уявлення щодо походження укр їнських етногр фічних груп від різних д вніх кельтських чи тюркських племен, які зійшли з історичної рени з довго до поч тків м сового освоєння гірської к рп тської місцевості. с ме співвідношення різних груп переселенців з півдня, півночі, з ходу і сходу (ще р з н голосимо, що це було здебільшого руське (д вньоукр їнське) н селення), т кож уст лення х р ктерних рис тр диційного господ рств й тр диційної культури під впливом різних природних умов 
вплинуло н йбільше н формув ння укр їнських к рп тських етногр фічних груп (бойків, лемків, гуцулів). уський (д вньоукр їнський) етнічний субстр т, як перев жний у процес х південної колоніз ції хідних рп т, зумовив т кож виділення етногр фічної групи гур лів, як в ході трив лих і скл дних етнічних процесів з умов іноетнічного колоніз ційного т культурного тиску, територі льної відд леності від інших укр їнських етнічних земель ст л скл довою польського т слов цького етносів. н слідок унік льного поєдн ння скл ду різних груп мігр нтів в особливих гірських умов х сформув лися й с мобутня к рп тськ тр диційн культур, що скл л широкий пл ст

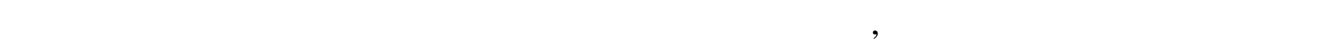
м ють усі підст ви формув ння оригін льних н ціон льно зн чущих смислів, форм i конструкцій.

1. олощук . “усь” в горському королівстві ( -друг половин V ст.): суспільно-політичн роль, м йнові стосунки, мігр ції. в но- p нківськ: ілея, 2014. 496 c.

2. ошко . . вич єве пр вон селення кр їнських рп ті рик рп ття V-XIX ст. ьвів: нститут н родозн вств кр їни, 1999. 337 c.

3. ошко . . селення кр їнських рп т V- VIII ст. селення. ігр ції. обут. .: ук. думк , 1976. 203 с.

4. римич - уч сний погляд н проблему волоського пр в // тнічн історія н родів вропи. ., 2001. . 110-116.

5. рушевський . . сторія кр їни- уси. . 1. ьвів, 1904. 655 с.

6. рушевський . . тері ли до історії суспільно-політичних і економічних відносин хідної кр їни (1361-1536) // п. . 1906. . 63. . 214-221.

7. обільник . оходження к рп тської і підк рп тської шляхти // овий ч с. 1936. . 105. 12 тр вня.

8. ом рницький . о землиця рідн [ лектронний ресурс]. ежим доступу: https://knowledge.allbest.ru/history/2c0b65625b3ad78a4c43b88421216d27_0.html

9. ящук. . еогр фічні н зви кр їнських рп т і прилеглих територій. .: , 1993. $204 \mathrm{c}$.

10. ожко · . рп тські шляхи т їх оборон // кр. іст. журн. 1990. № 10. 86-97.

11. еменюк . сторія укр їнського н роду. ьвів: пріорі, 2010. 608 с.

12. кочиляс . лич після лич : ониззя ( усо- л хія) у - V ст. т утворення олд вського князівств // няж доб : історія і культур . ьвів, 2011. ип. 5. . 29-72.

13. ливк . лицьк дрібн шляхт в встро- горщині (1772-1914 p.p.). в нор нківськ: істо ,2009. 217 с.

14. уляк . олд вск я усь // усин. 2010. № 2. . 10-18.

15. ерлецький . ротопл сти роду р го- сів. ьвів: рі д плюс, 2011. 192 с.

16. ивод $p$. . тнічні тр диції у скот рстві // тногенез т етнічн історіян селення кр їнських рп т. ьвів, 2006. . 2. . .52-124. 

ISSN 2078-6441. Вісник Львівського університету. Серія географічна. 2018. Випуск 52

17. ндр . . олоське пр во т особливості його з стосув ння н укр їнських землях ( $-\mathrm{V}$ ст. ст.): втореф. дис. н здобуття н ук. ступеня к нд. юрид. н ук. ьвів, 2010. 21 с.

18. Dobrowolski K. Migracje woloskie na ziemiach dawnego panstwa polskiego // Pasterstwo Tatr Polskich i Podhala. Wroclaw, 1962. S. 89-121.

19. Stadnicki A. O wsiach tak zwanych wołoskich na północnym stoku Karpat. Lwów, 1848. $98 \mathrm{~s}$.

\section{REFERENCES}

1. Voloshchuk, M. (2014). “Rus” v Uhorskomu korolivstvi ( I-druha polovyna IV st.): suspilno-politychna rol, mainovi stosunky, mihratsii. Ivano-Frankivsk: Lileia, 496 p. (in Ukrainian).

2. Hoshko, Iu. S. (1999). Zvychaieve pravo naselennia Ukrainskykh Karpat i Prykarpattia $X I V-X I X$ st. Lviv: Instytut narodoznavstva NAN Ukrainy, 337 p. (in Ukrainian).

3. Hoshko, Iu. H. (1976). Naselennia Ukrainskykh Karpat XV-XVIII st. Zaselennia. Mihratsii. Pobut. Kyiv: Naukova dumka, 203 p. (in Ukrainian).

4. Hrymych, M. (2001). Suchasnyi pohliad na problemu voloskoho prava. Etnichna istoriia narodiv Yevropy (pp. 110-116). Kyiv (in Ukrainian).

5. Hrushevskyi, M. S. (1904). Istoriia Ukrainy-Rusy (Vol. 1). Lviv, 655 p. (in Ukrainian).

6. Hrushevskyi, M. S. (1906). Materialy do istorii suspilno-politychnykh i ekonomichnykh vidnosyn Zakhidnoi Ukrainy (1361-1536). Zapysky NTSh, 63. Lviv, 214-221 (in Ukrainian).

7. Kobilnyk, V. (1936, May 12). Pokhodzhennia karpatskoi i pidkarpatskoi shliakhty. Novyi chas, 105 (in Ukrainian).

8. Komarnytskyi, B. To zemlytsia ridna. Retrieved from https://knowledge.allbest.ru/history/2c0b65625b3ad78a4c43b88421216d27_0.html (in Ukrainian).

9. Liashchuk, B. F. (1993). Heohrafichni nazvy Ukrainskykh Karpat i prylehlykh terytorii. Kyiv: ISDO, 204 p. (in Ukrainian).

10. Rozhko, M. F. (1990). Karpatski shliakhy ta yikh oborona. Ukrainskyi istorychnyi zhurnal, 10, 86-97 (in Ukrainian).

11. Semeniuk, S. (2010). Istoriia ukrainskoho narodu. Lviv: Apriori, 608 p. (in Ukrainian).

12. Skochylias, I. (2011). Halych pislia Halycha: Ponyzzia (Ruso-Vlakhiia) u XII-XIV st. ta utvorennia Moldavskoho kniazivstva. Kniazha doba: istoriia i kultura, 5. Lviv, 29-72 (in Ukrainian).

13. Slyvka, L. (2009). Halytska dribna shliakhta v Avstro-Uhorshchyni (1772-1914 r.r.). Ivano-Frankivsk: Misto NV, 217 p. (in Ukrainian).

14. Suliak, S. (2010). Moldavskaia Rus. Rusyn, 2, 10-18 (in Ukrainian).

15. Terletskyi, M. (2011). Protoplasty rodu Draho-Sasiv. Lviv: Triada plius, 192 p. (in Ukrainian).

16. Tyvodar, M. P. (2006). Etnichni tradytsii u skotarstvi. Etnohenez ta etnichna istoriia naselennia Ukrainskykh Karpat, 2. Lviv, 52-124 (in Ukrainian).

17. Shandra, R. S. (2010). Voloske pravo ta osoblyvosti yoho zastosuvannia na ukrainskykh zemliakh (XIII-XVIII st. st.). Dissertation Abstracts International. Lviv, 21 p. (in Ukrainian). 
18. Dobrowolski, K. (1962). Migracje woloskie na ziemiach dawnego panstwa polskiego. Pasterstwo Tatr Polskich i Podhala. Wroclaw, 89-121 (in Polish).

19. Stadnicki, A. (1848). O wsiach tak zwanych wołoskich na północnym stoku Karpat. Lwów, 98 p. (in Polish).

m ття: н дійшл до ред кцї̈ 31.05.2017

доопр иьов н 26.09.2017

прийнят до друку 11.01.2018

\title{
THE PROBLEM OF THE SETTLEMENT OF THE MOUNTAINOUS AREA OF THE UKRAINIAN CARPATHIANS: CONTRADICTIONS OF METHODOLOGICAL APPROACHES AND INTERPRETATIONS
}

\author{
Myroslav Dnistryanskyy ${ }^{1}$, Natalia Dnistryanska \\ ${ }^{1}$ Ivan Franko National University of Lviv, \\ P. Doroshenko St., 41, UA - 79007 Lviv, Ukraine, \\ e-mail:m_dnister@ukr.net \\ ${ }^{2}$ Lviv Polytechnic National University, \\ General Chuprynka St., 130, UA - 79057 Lviv, Ukraine
}

The most controversial questions in research of settlement problems of the Ukrainian Carpathians are settling time, the role of different migratory movements and ethnic composition of immigrants. Historical records show that until the XIII century there was not an overall network of settlements in the mountainous areas of the Ukrainian Carpathians. Nevertheless, on the eve of that time, the Ukrainians quite rapidly adjusted directly to the foothills, Transcarpathian ways, they created defensive points in the highlands and carried out various nature use. Considering the socio-economic and security needs of the population of ancient foothill areas main migratory movement coming from the plains to mountain rivers flow to their origins, including the territory of Transcarpathia and Carpathian and Volyn and Podillya. The similarity place names on both sides of the Carpathians Ukrainian Transcarpathian confirm the influence of colonization movements that have left their traces in the mountains. Various historical and ethnographic artifacts indicate an important role in the settlement of the Carpathian mountain region south of colonization, i.e. relocation to the region population from the territory on the border of the middle and lower Danube, historic Transylvania and Moldova during the XIII-XVI centuries, which in the Commonwealth and some other states politically identified as "land Wlachs". The main component of ethnic-social colonization was humanity southern Slavic-Rusyn origin. Settling mountain areas of Ukrainian Carpathians influenced the formation of the social structure of Ukrainian society, particularly on the spread of Ukrainian gentry, which was originally founding villages and their families. Value of different groups of immigrants from the south, north, west and east, as well as instituting the characteristics of the traditional economy and traditional culture under various environmental conditions and led to the formation of ethnic groups of the Ukrainian Carpathians (Boyko, Lemko, Hutsuls).

Key words: settlement of the Ukrainian Carpathians, South colonization, Ukrainian ethnographic groups, toponymy of the Ukrainian Carpathians, Transcarpathian relocation. 